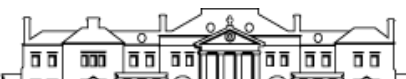

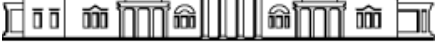

Levy Economics o

Institute

of Bard College

$\mathrm{N}^{-1}$

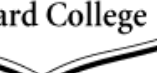

Working Paper No. 947

\title{
Ages of Financial Instability
}

by

\author{
Mario Tonveronachi* \\ University of Siena
}

February 2020

\begin{abstract}
* Paper presented at the Fifth Thomas Guggenheim Conference in the History of Economic Thought, Accademia dei Lincei, Roma, December 17-18, 2019. Thanks are due to Jan Kregel for the many suggestions that helped to greatly improve a previous draft of the paper. The usual caveats apply.

The Levy Economics Institute Working Paper Collection presents research in progress by Levy Institute scholars and conference participants. The purpose of the series is to disseminate ideas to and elicit comments from academics and professionals.
\end{abstract}

Levy Economics Institute of Bard College, founded in 1986, is a nonprofit, nonpartisan, independently funded research organization devoted to public service. Through scholarship and economic research it generates viable, effective public policy responses to important economic problems that profoundly affect the quality of life in the United States and abroad.

\author{
Levy Economics Institute \\ P.O. Box 5000 \\ Annandale-on-Hudson, NY 12504-5000 \\ http://www.levyinstitute.org
}

Copyright (C) Levy Economics Institute 2020 All rights reserved

ISSN 1547-366X 


\begin{abstract}
Starting from the mid-nineteenth century, this paper analyzes two periods of financial instability connected with financial globalization. The first culminates with the 1929 crisis, while the second characterizes the more recent experience starting from the 1970s. The period in between is divided into two subperiods. The first goes up to World War II and sees a retrenchment from globalization and the affirmation of a statist approach to national policy autonomy in pursuing domestic goals, for which we take as examples the New Deal, financial regulation, and the new international cooperative approach finally leading to Bretton Woods. The second subperiod, marked by the new international monetary order and limited globalization, although appearing as a relatively calm interlude, conceals the seeds of a renewed push toward financial fragility. The above periods are synthetically analyzed in terms of the development and mutual fertilization of theories, institutions, and vested public and private interests. The narrative is based on two interpretative keys: the Minskyan theory of financial fragility and changes in the public-private partnership, mainly with reference to the financial sector for which the role of the State as guarantor of last resort necessarily ensues. The lesson that can be derived is that a laissez-faire approach to globalization strengthens asymmetric powers and necessarily leads to overglobalization, as well as to financial and economic instability, rendering it extremely difficult and socially costly for the State to comply with its role of financial guarantor.
\end{abstract}

KEYWORDS: Financial Instability; Financial Fragility Theory; Globalization; International Cooperation; Financial Regulation; Public-Private Partnership

JEL CLASSIFICATIONS: B00; E1; E31; E32; E4; F33; G18 


\section{INTRODUCTION}

After the recent financial crisis, it has been rather common among officials and analysts to argue that this time is not different because banking and financial crises always existed, so that what policymakers can do is to render financial fluctuations less frequent and severe. This should then be the perspective with which to read and appreciate the direction taken in postcrisis financial reforms.

The purpose of the present paper is to put the above argument into historical context both the facts, with the relatively short Bretton Woods period apparently representing a calm oasis between two ages of financial turmoil, and ideas, looking at the development of theories directed at explaining financial instability and at devising reforms and policies to cope with it. Given the limited space allowed to an anyhow not short paper, to render full justice to facts and ideas is an impossible task. The hope is that, like in the late medieval frescos, the few "vignettes" will be able to seize the salient features of the whole narrative.

Following Hyman Minsky, the analysis developed in the paper focuses on the inherent fragility and instability of the financial system, both at the domestic and international level, and on the stabilizing role of the State. A concise premise on the necessity of a structural public-private partnership in the financial sphere of a capitalist economy might help to better understand the arguments developed in the following sections. Independently of historical processes, in a capitalist system the bulk of finance must be private because its fundamental function of acceptance, that is the creation of credit, cannot rest on a soviet type of unibank system that would subject all economic decisions to centralized political control. However, because the creation of credit leads to the creation of liquidity by the private sector in competition with the monetary sovereign attributes of the State, and because its results might heavily conflict with public goals, a financial public-private partnership ensues in which credit creation is licensed to the private sector under explicit or implicit conditions. The latter refer to specific public goals and take the form of constraints on private activity, generally directed at making monetary policy effective and at disciplining the sector by way of financial regulation and supervision. These constraints may take different forms and exercise different degrees of public command, thus characterizing the nature and balance of the public-private partnership. This constrained 
structural license implies that the State has the obligation to act as guarantor of last resort against the bankruptcy of the financial system, thus converting eventual negative externalities coming from shortcomings of its constraints or from unavoidable events into public costs. A large part of this paper is devoted to discussing how this domestic partnership is influenced by the national and international degree of financial liberalization.

Section 2 encompasses the period going from the mid-nineteen century to the aftermath of the 1929 crisis. The increasing relevance of monetary and financial factors in expanding the breadth of economic fluctuations, or in producing short-term cycles on their own, spurs the attention of economists that, like Alfred Marshall, Ralph Hawtrey, John Maynard Keynes, and Irving Fisher, focused on the conflict between the inherent instability of credit and the constraints on national policy autonomy posed by the then-dominant international gold standard. More generally, their theories lay down the basis for discussing the nature and reach of public command on private domestic and international finance. The post-World War I disorder and 1929 global crisis marks the culmination of our first age of financial instability. Its nature and consequences further fueled theoretical and policy elaborations on international reforms and on the fiscal, monetary, and regulatory role of the State.

Section 3 is devoted to the post- 1929 period up to the end of World War II, where we can discern a path toward a more assertive role of the State, and its nascent welfare orientation. In this perspective, we analyze two accomplishments: the Glass-Steagall reform of the US financial system and the process finally leading to the Bretton Woods Agreement. Their weaknesses, due in part to a limited vision of the functioning of the financial system and to the pressure by financial vested interests, were responsible for their later demise.

Section 4 analyses the short interregnum represented by the Bretton Woods period. Its low exposure to private global finance and domestic constraints on banks' operations may be at least in part responsible for its limited number and depth of financial crises. However, the weaknesses highlighted in the previous section and a resurgent laissez-faire movement favored the gradual reorientation toward fragile configurations so that, in a Minskyan fashion, a period of relative financial tranquility was the harbinger of future instability. 
Section 5 explores the post-Bretton Woods period. It focuses on three main paths where the increasing domination of vested interests helped by the theoretical laissez-faire approach produces the reversal of State protagonism, a heavy qualitative and quantitative evolution of finance, and related changes in financial regulation and supervision. Their implications for financial fragility soon found expression in the long string of financial crises, which - given their increasing frequency, strength, and welfare losses - have characterized this period, showing the unsustainability of the current laissez-faire type of public-private partnership.

Building on the previous narrative, section 6 offers some concluding remarks on how the balance of power in the public-private partnership can suffer large swings when vested interests are supported by ad hoc theories, independently of the soundness of the arguments and of experience.

\section{FROM THE NINETEENTH CENTURY TO THE AFTERMATH OF THE 1929 CRISIS}

Since the nineteenth century, many economies experienced relevant short-term fluctuations in aggregate demand, production, credit, and prices, adding a monetary flavor to longer-term growth paths and fluctuations. At least this was what impressed the economic profession as testified by the increasing number of publications devoted to fluctuations (often termed "trade cycles") and to monetary matters. Marshall's work offers a precious perspective of the interplay of this economic evolution with the attempts to incorporate it in economic analysis.

Useful to stress is that Marshall's interest in economic theorizing much owes to his deep involvement in social problems and to his opinion that capitalism could offer to the working class better opportunities than previous systems, mainly because of technical progress. Better opportunities, not perfect results. Marshall is far away from the static optimality coming from the Walrasian general equilibrium theory, hence from full employment results. This is primarily because of uncertainty, which he linked to the dynamics of capitalism and considered enough cause for transforming theoretical free competition into an imperfect one, for giving relevance to monetary and speculative factors, and to make distance from Say's law. Time, both in its logical 
and historical dimension, takes therefore a prominent role in Marshall's theorizing and in his applied and policy works. At least implicitly, uncertainty_-viewed as the lack of full knowledge of the changes coming from the inner functioning of capitalism-explains why as a reformer he opposed radical policy interventions and saw in discretionary public policies the danger of introducing distortions in the natural and vital forces of capitalism. This is the general inheritance that he left to be variously exploited in the following years by his Cambridge "pupils."

Coming to financial instability, two long excerpts from the Economics of Industry (1879) clarify Marshall's position on the evolution of finance and on the role of endogenous credit creation and destruction in amplifying or creating economic fluctuations.

[T] he modern system of credit enables a man who has neither money nor anything that immediately represents money, to obtain from a banker or other money dealer the means of purchasing goods. He can do this not only on his own credit (as when a bank allows him a "Book credit"), but on the credit of others who have undertaken to pay him money at a future date (as when he "discounts a Bill").

The business of the civilised world has increased very rapidly during the present century; and an enormous amount of coin would have been required to carry it on with the present prices. If credit had not found substitutes for coin, there would have been so great demand for the precious metals, that their purchasing power would have become many times as great as it actually is; prices would have been very low. The growth of credit supplies a permanent substitute for the precious metals, and therefore affects their Normal values. But credit fluctuates, and each fluctuation alter their Market values.

For instance, an expansion of credit coincided with the influx of precious metals consequent to the discovery of the Californian and Australian mines, and increased the upward tendency of prices. But in 1857 there was a crisis; that is, many trading firms were unable to pay their debts, credit was violently contracted, and prices fell, although the store of precious metals in the country was growing as rapidly as ever. After a time credit began to expand again, and prices rose till 1866 when there was another crisis, and prices fell (Marshall and Paley 1879, 151-52).

Whatever a period of rising credit starts,

\footnotetext{
${ }^{1}$ To appreciate the full contour of Marshall's ideas and contributions it should be recognized that, as it often occurs, his theoretical works do not always make justice of the richness of his understanding of contemporary economic problems as can be derived by his more applied and policy-oriented works. The reminiscences and the selection of his works contained in Memorials of Alfred Marshall, edited by Pigou (1925), help to delineate such contour.
} 
[t]his movement goes on for some time, till at last an enormous amount of trading is being carried on by credit and with borrowed money. Old firms are borrowing in order to extend their business; new firms are borrowing in order to start their business, and speculators are borrowing in order to buy and hold goods: trade is in a dangerous condition. Those whose business it is to lend money are among the first to read the sign of the times; and they begin to think about contracting their loans. But they cannot do this without much disturbing trade. If they had been more chary of lending at an earlier stage, they would simply have prevented some new business from being undertaken; but when it is once undertaken, it cannot be abandoned without a loss of much of the capital that has been invested in it. [...] The lenders of capital already wish to contract their loans; and the demand for more loans raises the rate of interest very high. Distrust increases, those who have lent become eager to secure themselves; and refuse to renew their loans on easy or even on any terms. Some speculators have to sell goods in order to pay their debt; and by doing so they check the rise of prices. This check makes all other speculators anxious, and many rush in to sell. For a speculator who has borrowed money at interest to buy goods may be ruined if he holds them a long time even while their price remains stationary; he is almost sure to be ruined if he holds them while their price fall. When a large speculator fails, his failure generally causes that of others who have lent their credit to him; and their failure again that of others. [...] As credit by growing makes itself grow, so when distrust has taken the place of confidence, failure and panic breed panic and failure. The commercial storm leaves its path strewn with ruin. [...] Thus the state of trade, to use the famous words of Lord Overstone, "revolves apparently in an established cycle. First we find it in a state of quiescence, -next, improvement, -growing confidence, -prosperity, -excitement, -over trading, convulsion, -pressure, -stagnation, -distress, -ending again in quiescence." (Marshall and Paley 1879, 152-53)

The endogeneity of credit renders the procyclicality of prices largely independent from changes in the quantity of the precious metals that serve as money. Lenders, producers, and speculators act according to their expectations of future prices, and the excess in the increase or decrease of credit and output with respect to what would be justified by the physiology of changes affecting the economic system depends on the lack of synchronism between prices and costs - with the latter, especially labor costs, lagging behind in both directions of price changes. This is the basis for Marshall's later proposal of a tabular standard: that is, of full indexation. The crisis develops in terms of what Fisher later called debt deflation, where the attempt to make position by selling positions, as Minsky puts it, produces the failure of both debtors and lenders. Marshall's emphasis on speculation on goods may perhaps refer to merchants' inventories ${ }^{2}$ and to the financing of the commodity trade that characterized the City of London. In any case, as we shall see in section 5, there is a substantial difference between leveraged speculation on goods, whose prices substantially move in synchrony with the overall rate of inflation and where debt validation depends on the same prices that validate expected returns from production, and

\footnotetext{
${ }^{2}$ See Marshall and Paley (1879: Book III, ch. II), where expectations on future prices govern, especially for primary commodities, the supply to the market by wholesale merchants, whose action is therefore intrinsically speculative and procyclical.
} 
leveraged speculation on financial assets, where debt's validation depends on the realization of expected prices of financial assets.

Marshall reaffirms the above analysis in book IV, chapter III, of Money, Credit and Commerce (1923), taking several excerpts from the earlier book. He also adds in chapter IV an analysis of the stock market where marginal bulls and bears are influenced by both business confidence and credit conditions. A change of the central bank's rate of discount may thus strengthen the bullish or bearish position of the market, capable of creating cumulative price movements in both directions, which would take with them the long-term interest rate net of risk. Although the demand for fixed investment is sensitive to the long-term interest rate (see, e.g., Marshall and Paley [1879: ch. X]), short-term fluctuations do not clearly include the effects of changes in the monetary market on investment decisions. This, presumably, either because the sum of the risk premium's anticyclical movements and of the real risk-free interest rate's procyclical movements do not have a clear sign, or because Marshall considers fixed investments more sensitive to the longer-term conditions of both credit and business profitability.

Further developments in the financial aspects of the fluctuations characterize a large part of the economic literature in the following years, in particular the works of the so-called Cambridge School.

Although often associated with the Cambridge School, Hawtrey began studying economics as an autodidact when working at the Treasury after leaving Cambridge. Perhaps for this reason, his first book, Good and Bad Trade (Hawtrey 1913), contains no reference to contemporary British economists, with the only academic reference being to Fisher. Hawtrey's later book, Currency and Credit (Hawtrey 1919) just refer to Keynes's Indian Currency and Finance, naming Marshall in the third (1928) edition, and with the only reference to the principle of the purchasing power parity of money. As a matter of fact, Good and Bad Trade expands Marshall's succinct analysis into a full-fledged theory of the trade cycle with predominant monetary and financial features. ${ }^{3}$

\footnotetext{
${ }^{3}$ Hawtrey's lack of references to Marshall's works was perhaps also due to the fact that the basic propositions of the theory of economic fluctuations were considered at his time common knowledge by the economic profession. For a discussion of this issue and further references, see Kregel (1977). Less clear is why, when speaking of the ways to contain fluctuations, Hawtrey does not discuss Marshall's tabular standard.
} 
In explaining the cumulative movements of credit, aggregate demand, and production, Hawtrey does not count on the Marshallian lack of synchronism between prices and costs, although allowing for it, but considers the quantitative impact of an initial disturbance on aggregate demand and production, with current and expected price changes not necessarily being a cause of the initial movements. Furthermore, he substitutes Marshall's procyclical demand for goods by speculators with the demand coming from the wholesale merchant's nonspeculative management of inventories. The analysis of the endogenous creation and destruction of credit occupies a large part of both books in order to show "the inherent tendency towards fluctuations in the banking institutions" and the "inherent instability of credit" (Hawtrey 1913, 199; Hawtrey $1919,86)$, making the latter the main cause of financial excesses, crises, and fluctuations. This is why Hawtrey has been generally considered the initiator and most preeminent advocate of the monetary theory of the trade cycle.

Whatever the cause of the initial perturbance, Hawtrey looks at its effects on aggregate demand, production, and employment, adopting a complex adjustment process whose actors are consumers, retailers, wholesale merchants, producers, banks, real and financial investors, the central bank, and the foreign sector. On the monetary side, yet worthy of reading, is Hawtrey's long essay, The Art of Central Banking, included in the book with the same title (Hawtrey 1932). ${ }^{4}$ The first part of the essay is devoted to the historical development of the Bank of England's function as a lender of last resort (LOLR). LOLR is presented as an essential characteristic of a central bank, enhanced by its privilege to issue legal tender, and is linked to discounting operations when the banking system is short of currency. Being the system based on "customary conditions" of access to the Bank, the latter could not refuse accepting customary collaterals, thus facilitating the expansion of credit. When, due to these operations and/or to other circumstances, the Bank's legal gold requirements is put at risk (or the entire volume of gold reserves is negatively affected), the central bank makes recourse to the rate of discount and to open market operations, although quantitatively the latter so far had played a limited role. However, the necessity to undo the excessive credit growth gives way to deflation.

\footnotetext{
${ }^{4}$ The term "art" reflects how complexity affects monetary policy "not merely with the relation of cause to effect, but with the relation of means to end" (Hawtrey 1932, vi). In Hawtrey's analysis, complexity is reflected in the large set of connections and alternative reaction functions that, however, invariably result in cumulative upward or downward aggregate movements.
} 
Some of the richness and novelty of Hawtrey's analysis, as well as its deficiencies, were well caught by Nicholas Kaldor when asserting that "but for the distinction between short and long term investment and short and long term lending, his theory could be said to have anticipated the Keynesian theory by twenty years or more. Mr. Hawtrey persisted, however, through the successive presentations of his views, in believing that there is a sharp difference between the way the money market operates and the way the long term capital market operates, viewing the latter in the classical or neo-classical manner as a mere channel in the investment of savings" (Kaldor 1960, 7). ${ }^{5}$

For what mainly concerns us here, two aspects of Hawtrey's analysis are particularly relevant. First, is the necessity of considering open economies and the balance of payments' structure and dynamics in the context of specific international monetary frameworks. Their influence on domestic financial instability is relevant through the constraints posed to the creation or destruction of credit mainly due the policy reaction by the central bank. The degree of elasticity with which the central bank managed the gold standard in relation to the currency reserves it held and those held by the banks influenced credit excesses and the subsequent need to impose discipline, generating crisis and deflation. ${ }^{6}$ Second, changes in short-term interest rates are relevant, independently of their influence on long-term ones, because they affect (as we have already seen in Marshall) the decisions and solvency of positions highly exposed to short-term debt, which in his analysis refers to wholesale merchants and financial dealers. ${ }^{7}$

\footnotetext{
${ }^{5}$ Kaldor's comments come from his 1938 Economica review of Hawtrey's 1937 Capital and Employment, which contains a critique of Keynes's General Theory. Hawtrey's position, first postulated in Good and Bad Trade, formed the basis of what would later become known as the "treasury view," according to which public expenditure financed by new debt would subtract an equal amount of resources from private fixed investment for any given amount of "investible resources." The latter concept is often used in the literature of the time but hardly is its precise meaning well specified. Keynes's point was that changes in the money market affect the amount of investible resources and the price in the securities market. On the other hand, Hawtrey had criticized the Treatise on Money in his correspondence with Keynes, a compact version of it being later published in his The Art of Central Banking, for not clearly considering the fluctuation of savings associated with the fluctuation of income, a critique that possibly influenced Keynes's transition to the General Theory.

${ }^{6}$ For limiting those excesses, Hawtrey recommended the coordination among central banks, a proposal that he presented at the 1922 Genoa Conference in the context of the postwar resumption of the gold standard, whose approval was later made ineffective by central bank hostility.

${ }^{7}$ The attention to financial structures and to their sensitivity to interest rate changes will later characterize Minsky's financial fragility theory.
} 
Keynes's Treatise on Money (1930) represents the attempt to critically open the received Marshallian wisdom, as further elaborated by himself and Hawtrey, to the contributions coming from Continental Europe introduced by D. H. Robertson in Cambridge's discussions. ${ }^{8}$ Essentially, this is done by focusing on the role of investments in fixed capital in generating fluctuations of prices and production. Adding to a Schumpeterian-like analysis on the waves of innovation how financial factors affect the pace of investments, Keynes escapes from a pure monetary theory of the trade cycle while keeping the influence of financial factors: "whilst the stimulus to a credit inflation comes from outside the banking system, it remains a monetary phenomenon in the sense that it only occurs if the monetary machine is allowed to respond to the stimulus" (Keynes 1930: vol. II, 85-86; vol. I: ch. 13.I). In the Treatise, a mismatch between ex ante decisions on investment and saving produces disequilibrium, changes in the price of consumer and investment goods, and extra profit or losses, leading to an upward or downward revision of production in the following period. ${ }^{9}$ As for Marshall, Hawtrey, and Wicksell, there are no self-equilibrating forces and the initial change produces cumulative movements and finally fluctuations. While Hawtrey goes deeper into the dynamic analysis of the cumulative processes, Keynes, by shifting his focus to long-term fixed investments, is more interested in analyzing the relationship between short- and long-term credit and interest rates, and more generally in the theoretical and institutional aspects of the interplay between the financial system and monetary policy.

Like Marshall and Hawtrey, Keynes starts from the "inherent instability" due to the endogeneity of credit. In a closed system, if no cash is used and banks do not hold cash reserves (settling their interbank debt by transferring assets) there is no limit to the creation of bank money, "provided that they move forward in step [...]. A monetary system of this kind would possess an inherent instability; for any event which tended to influence the behaviour of the majority of the banks in the same direction whether backward or forward, would meet with no resistance and would be capable of setting up a violent movement of the whole system. [...] [Although] checks on this instability have been devised $[\ldots][n]$ evertheless this tendency $[\ldots]$ is always present to a certain extent and has to be reckoned with," being of the utmost importance in a closed system

\footnotetext{
${ }^{8}$ See Robertson's A Study of Industrial Fluctuations (1915) and Banking Policy and the Price Level (1926).

${ }^{9}$ For an analysis of the definitions and of the fundamental equations that constitute the theoretical framework of The Treatise on Money, see Tonveronachi (1983).
} 
(Keynes 1930: vol. I, 23-24). However, perfect endogeneity of bank money is limited both by the drain of cash — because the volume of cash payments bears some proportion to depositsand by the reserves held with the central bank to deal with daily net interbank claims as calculated by the clearing house: "Thus it is the aggregate of the reserve resources which determines the 'pace' which is common to the banking system as a whole" (Keynes 1930, 24 25).

\begin{abstract}
Assuming that the central bank is also the note-issuing authority, the aggregate reserve resources of the member banks will be under the control of the central bank, provided the latter can control the aggregate of its note issue and its deposits. In this case the central bank is the conductor of the orchestra and sets the tempo. [...] [I]t may be that the member banks themselves have some power, perhaps within limits, of increasing at will their deposits with the central bank or the amount of the notes which they draw out of its note-issuing departments. In this case [...] it will be difficult to restrain the inherent instability of the system. (Keynes 1930,26)
\end{abstract}

The next logical step is to show that the endogeneity of credit concerns the financing both of current production and investment in fixed capital (the issue in the Hawtrey-Keynes discussion recalled by Kaldor):

\begin{abstract}
In actual fact the banking system has a dual function - the direction of the supply of resources for working capital through the loans which it makes to producers [...] and, on the other hand, the direction of the supply of resources which determines the value of securities through the investments which it purchases directly and the loans it makes to the stock exchange and to other persons who are prepared to carry securities with borrowed money [...] At any rate, when we are considering the regulative powers and functions of the banking system, we must study its influence over the rate of investment in fixed capital at least as much as its influence over the rate of investment in working capital; indeed it is probably true that it cannot, in most cases, exert an effective influence over the latter except through its influence over the former. (Keynes 1930: vol II, 310-12; italics in the original)
\end{abstract}

In the Treatise, equilibrium requires that total investment (in fixed, working, and liquid capital) equals the amount of savings, and disequilibrium is caused by the variability of the former with respect to the relative stability of the latter. Being fixed investment-sensitive to the interest rate, the market rate that equates savings and investment is called, following Wicksell, the natural rate. After having disposed of the causal relevance of working capital, Keynes had to show the causal and policy irrelevance of Hawtrey's focus on inventories (liquid capital) and the relevance of the influence of short-term interest rates on long-term interest rates, hence on fixed 
investment. These two issues may be illustrated following the analysis presented in Kregel (1993, 2010b).

The first issue relates to Hawtrey's assertion that the inventories held by wholesale merchants are highly sensitive to changes in the interest rate, so that changes in policy rates could be used as a countercyclical measure. Considering spot and forward markets for durables in the presence of carrying costs of inventories (warehouse, depreciation, and interest charges), Keynes's analysis shows that when no surplus inventories exist, spot prices must be higher than forward prices (backwardation) to make room for the cost of hedging against the future fluctuation of prices. When surplus inventories exist (e.g., due to a fall in aggregate demand), the condition for holding that surplus is that spot prices must become lower than forward prices (contango) to make room for carrying costs and for backwardation. The difference increases with the length of the period that is expected for returning to "normal" prices, which is especially relevant when short-term supply rigidities exist. However, "[i]n no case can surplus stocks exist alongside of normal production. Recovery - broadly speaking - cannot begin until stocks have been absorbed [...] The efforts to get rid of surplus stocks aggravate the slump, and the success of these efforts retards recovery" (Keynes 1930: vol. II, 130). ${ }^{10}$ In other words, the initial fall in aggregate demand produces a fall in prices; though the fall in prices may continue until it satisfies the above condition, it does not make surplus inventories to disappear, so that recovery in prices and production cannot start if aggregate demand is not increased either by higher fixed investment induced by lower interest rates or by public investment. According to Keynes, feasible decreases of the bank rate would produce small changes in carrying costs due to the presence of the other components; therefore, they would not work as purported by Hawtrey in increasing the demand for inventories, hence of production. On the contrary, due to the expectation of future prices that they may generate, their "influence will often tend to operate just the wrong way-inducing [dealers] to increase stocks when trade is reviving and to reduce them when it is falling away" (Keynes 1930: vol. II, 130).

\footnotetext{
${ }^{10}$ These results also descend from Keynes's theory of short-period prices, according to which the proportional decrease in price relative to their normal level multiplied by the proportionate fall in production below its normal level is equal to the proportion of carrying costs to normal prices multiplied the proportion of surplus inventories to a year's consumption; see Keynes (1930: vol. II, ch. 19, sections IV and V). For an explanation of how this equation is arrived at and its policy implications, see Kregel (1993). Kregel (2010b) also shows that the development of the analysis of spot and forward prices characterizes Keynes's contribution to the theory of finance from his early works up to the General Theory (chapter 17).
} 
The second difference from Hawtrey, which we have introduced with Kaldor's comment on Hawtrey and is extensively analyzed in the Treatise (Keynes 1930: vol. II, 319-31), concerns three channels through which changes in short-term interest rates influence long-term ones: 1) affecting the relative strength of short and long positions, also by firms when deciding to utilize part of their liquid reserves kept as securities, either by selling them or posting them as collateral for short-term funding; 2) through changes in the portfolio composition of financial firms by changing the relative merit of the differences in liquidity and returns, taking also into account the need to cover funding and operational costs; 3) affecting speculation in the securities market, based on short-term expectations of asset price changes, which is fostered or restrained by changes in short-term funding costs. Since for securities the carrying costs are limited to interest charges - differently from the case of inventories changes - in the short term, the interest rate exerts a strong influence through the above channels. ${ }^{11}$ Because at that time monetary policy was chiefly based on controlling market short-term interest rates, these channels were essential for asserting its influence on investment decisions. Since deflation was considered the main challenge for monetary policy, when the method for controlling fixed investments via the discount rate is partly ineffective, for instance because it is applied with a delay or in the presence of an acute slump, Keynes proposes to use open-market operations "to the point of saturation" (i.e., up to obtaining the desired long-term rate), resembling the recent experience with quantitative easing (Keynes 1930, 331-35).

As a result, in a closed system with convertible currency, credit fluctuations cannot be large if they are not accompanied by passive behavior by the central bank. Differently, the then-ruling gold standard was imposing constraints on the national autonomy of an open system. ${ }^{12}$ As we have already seen with Hawtrey, the need to maintain external parity within the gold standard points to the central bank's limited power in tailoring monetary policy to internal needs. Whereas for a moderately open economy like the United States the degree of freedom of monetary policy was higher, for the UK, where international trade and international lending made up a considerable "proportion of its economic life," Keynes proposes that "the

\footnotetext{
${ }^{11}$ In his comments to the Treatise, Hawtrey (1932), following Marshall, opposes on empirical grounds the influence of changes in long-term interest rates on investment decisions. Therefore, even if the disconnection between shortand long-term credit were not complete, possible changes in long-term interest rates would not influence decisions on fixed investment.

${ }^{12}$ Chapter 35, volume II of The Treatise on Money is devoted to the problem of national autonomy.
} 
Government subsidises approved type of domestic investment or itself directs domestic schemes of capital development" (Keynes 1930, 335-37).

The theoretical framework of the Treatise is the basis for Keynes's analysis of the slump that followed the 1929 crisis. After WWI, the need for reconstruction and the diffusion of technical progress were responsible, at least up until 1925, for the high profitability of investment and production - the "natural rate of interest," in the Treatise's terminology—which thus did not suffer from the high levels of market interest rates coming from several sources, such as the prudential restriction of monetary policies adopted after the return to the gold standard, the related demand for international reserves by central banks and member banks, the demand for credit by distressed borrowers (mainly governments), and the demand from speculative borrowers participating in the feverish bull movement in securities markets. As a result, market interest rates were maintained at high levels by borrowers and not related to productive investments. When, in the middle of the 1920s, the sundry causes that had kept the natural rate high began to disappear, the high market interest rates began to exert their negative influence on fixed investment, production, and employment, finally leading to lower prices and losses, and a downward spiral. An internationally concerted action to push down policy and market interest rates, particularly using open-market operations "to the point of saturation," would have been necessary because the increase in the number of distressed borrowers and higher risks militated against the descent of market rates in a measure necessary to reach a new equilibrium with the natural rate (Keynes 1930, 338-47).

The last chapter of the Treatise builds on the postwar experience up to the 1929 crisis and discusses the problem of international management. Keynes outlines a proposal with two main goals: the necessity of a supranational agreement on international cooperation, and making the gold standard more flexible in order to increase the autonomy of national policies. The specific reform proposals offered by Keynes, Hawtrey (see footnote 8), ${ }^{13}$ and Fisher (whose contribution is discussed below) were rendered obsolete by the final abandonment of the gold standard in the 1930s, being therefore more interesting as critiques than for their specific content. Despite their

\footnotetext{
${ }^{13}$ In The Art of Central Banking, Hawtrey also offers a detailed and rich analysis of the causes and consequences of the 1929 crisis, which, although viewed from the English perspective, is centered on international post-WWI developments and leads to a reaffirmation of his position on international cooperation.
} 
differences, the three authors agree on the above two goals because the national policy autonomy necessary to rein in the inherent instability of credit depends on the international institutional framework.

The 1929 crisis and its aftermath led Fisher to systematize the phenomenon of fluctuations in his 1932 book, Booms and Depressions, which was later synthetized in his 1933 Econometrica article, "The debt-deflation theory of great depressions." As in the authors previously discussed, the boom was the result of the cumulative endogenous creation of credit; however, the distinctive character of Fisher's work lies in going deeper into the dynamics of debt.

Fisher poses the question: Is there is a way to define the right amount of debt (and credit)? To this end he proposes the concept of a margin of safety: "Everyone who is not a gambler, provides himself with a margin of safety. He puts a buffer between his debts and the collector" (Fisher 1932, 9). This buffer is represented by the difference between assets and liabilities (i.e., capital), and its sufficiency depends not only on its level but also on the quality of assets and liabilities, specifically on their maturity: "Slow assets and quick liabilities (such as call loans) require a larger buffer than quick assets and slow liabilities" (Fisher 1932). Capital then serves as a buffer against unforeseen losses and liquidity strains: "Can a more definite criterion be devised for the community than the individual? In any event, such guides will have to be considered as the ratio between the nation's income and certain fixed expenses, like taxes, rent, and interest; the ratio between the income and the accumulated volume of outstanding debts; the ratio between debts and the gold on which the banks (in a gold standard country) base their loans. As low income endangers the debtors, low gold endangers the creditor banks, which then begin to press the debtors" (Fisher 1932, 10).

Apart from individual misjudgments, macroeconomic and international factors may negatively affect what were considered appropriate margins of safety, putting the entire system in an overindebted position. The chief cause of the realization that debt is overextended is the disappointment in current and expected earnings, which affects the confidence in the ability to service the debt. Hence, when overindebtedness: 
is discovered and attempts are made to correct it, distress selling is likely to arise. That is, in order to protect the creditors, some of the possessions of the debtor may have to be sold - his stocks, his bonds, his farmlands, or whatever his available assets may be. The debtor may choose $[\ldots]$ to facilitate liquidation by selling some of his property $[\ldots]$ or his bank or his broker may cash in on the debtor's collateral; or the mortgagee may foreclose the mortgage; or the debtor may go in bankruptcy, and the trustee in bankruptcy may then auction off his assets. [...] When a whole community is involved in distress selling, the effect is to lower the general price level. (Fisher 1932, 13-14)

Price deflation is the engine that transforms the initial loss of activity into a cumulative downward movement. Again, debt and its cost take the central stage. While nominal debt is decreasing (by distress selling and bankruptcy), lower prices increase the burden of debt—both its real value and the real rate of interest - while lower production decreases the amount of real profits available to cope with it. When price deflation is faster than the reduction in nominal debt, its residual real value continues to increase and firms' net worth declines; when the latter becomes negative, further bankruptcies ensue, so that the depression goes on until overindebtedness disappears and confidence gains traction. ${ }^{14}$ An initially slow recovery soon converts into a boom, not secondarily because, with price inflation substituting deflation, the real burden of debt decreases, giving a further push to higher expected profits.

Using the previous scheme to analyze the causes and consequences of the 1929 crisis, Fisher explains how in the previous years the United States were characterized by the pyramiding of the debt structure (helped by accommodative Federal Reserve policy), a feature that, as we shall see later, was experienced in more sophisticated forms starting in the 1980s. In the period 192129 , nonfinancial firms preferred issuing stocks rather than bonds, thus apparently avoiding the debt trap. However, individual investors bought stocks with debt (mainly through margins with brokers), which, being debt on call, created a more unstable way of financing the entire system than bonds. Furthermore, the abundance of stocks produced a rapid increase in the number of investment trusts that invested both their clients' money (mainly borrowed) and their own shortterm borrowed funds in stocks. Thus, the stock market boom led the magnification of the debt pyramid and its collapse readily led to a crisis of overindebtedness.

Fisher's remedies against the insurgence of ample debt cycles are related both to booms and depressions. To avoid excesses in the creation of credit, the quantity of money (including of

\footnotetext{
${ }^{14}$ For a critical discussion of these issues, see Kregel (1999).
} 
bank money) should increase at the same pace of the volume of transactions, what later became Friedman's golden rule. For restraining booms and depressions, the central bank should be permitted unbounded use of the discount rate and open market operations, the latter acting much faster than rates. Another proposal, similar to Marshall's tabular standard, consists of giving flexibility to debt service by adopting full indexation of debt (mortgages included) and interest rates. Public works are considered only "palliatives," a temporary measure of assistance for unemployed people in amounts too restricted be macro-significant. ${ }^{15}$ Noteworthy are some suggestions that points to the need to introduce measures of financial regulation and supervision:

\begin{abstract}
Any expedient should be adopted, therefore, which would retard the pyramiding of the debt burden - or (if the pyramid succeeds in getting itself erected) would retard its distress liquidation. In anticipation of booms, some of the superfluous and nonproductive lures to over-indebtedness might be withdrawn - for instance, speculative temptations like the capital gain tax. And the so-called bank affiliates, which are suspected of undue speculation, might be held in check by laws exposing their accounts to the same publicity that is applied to the banks with which they are affiliated. Also, American banks might show less hospitality to stock market collateral and press still further the policy which they have in recent years copied from abroad and are already using - the policy of lending on balance sheets - being careful, of course, to check balance sheets with income statements. Also, in the interest of small corporations and other modest borrowers, more facilities might be made for the function of lending intermediate amounts for intermediate periods. At present the nearest approach we have to a loan for an intermediate period is usually a sort of gentleman's agreement on the part of a commercial bank to renew a short term loan. This is a perversion of commercial banking; and the result is that, when an emergency arises, the commercial bank must either break its promise or be handicapped by a "frozen" loan. (Fisher 1932, 116-17; italics in the original)
\end{abstract}

Indeed, as argued in this paper's introduction, financial regulation constitutes one of the legs of our narrative, which is necessary for keeping financial instability under control in a closed as well as in an open system. In the latter case, the problem of consistency exists for the triad represented by the international framework, national policy autonomy, and financial regulation.

Enlarging the aftermath of the 1929 crisis to encompass Keynes's General Theory (1936), clear analytical improvements were gained with respect to the Treatise on Money and to the contributions of the authors discussed above. While some improvements represent important refinements and generalizations of previous positions (like the crucial and all-embracing role

\footnotetext{
${ }^{15}$ This was the experience of the first phase of the New Deal, when F. D. Roosevelt's initiatives were constrained by the political opposition to a large public deficit and he had to recur to the flexibilization of monetary policy as a way to increase prices, especially agricultural ones. An interesting narrative along these lines is presented by Rauchway (2015).
} 
given to uncertainty), others represent pathbreaking novelties, like the liquidity preference theory, which constitutes the pillar for a new theory of the rate of interest and of asset pricing (Keynes 1936: ch. 17) ${ }^{16}$ However, as far as the role of financial factors in economic fluctuations is concerned, the General Theory adds nothing to the previous analyses. On the contrary, chapter 22, "Notes on the Trade Cycle," appears to be rather orthodox to a Post-Keynesian reader because cyclical movements and crises are dominated by changes in the marginal efficiency of capital, with no attention given to financial structures, credit, and debt or to their dynamics.

\section{TOWARD AN ASSERTIVE ROLE FOR NATIONAL STATES}

According to Keynes, Hawtrey, and Fisher, the outbreak of the 1929 crisis was the culmination of post-WWI domestic and international events characterized by the explosion of public and private indebtedness in a context where the international prewar cooperative monetary architecture based on the gold standard had not been efficiently restored. Not secondarily, this was due to the complexity of adjusting the old architecture to the (difficult to read and digest) changes in the structure of economic and financial power validated by the war, especially among the victorious countries.

Independent of the specific problems that the major countries had to face, and of the different (uncoordinated) responses given to them, private finance took central stage. Using Fisher's terminology, a financial crisis is likely to explode when the margins of safety become so thin that they create an unsustainable state of overindebtedness. When this happened in the United States in 1929 , the crisis forcefully propagated to an already fragile international context.

The case of the United States is relevant for at least three reasons: because of the absence of relevant domestic problems inherited from the war that, as in Europe, might have produced a different path to the crisis; because of its acquired international dominance; and primarily because of its strong political reaction to the crisis that shifted the balance of power of the

\footnotetext{
${ }^{16}$ Although the bear position of the Treatise expresses a preference for liquidity, it was only later that Keynes realized that an alternative theory to the loanable funds proposition, which is untenable in a dynamic economy, had to express the rate of interest as the price at which an investor abandons liquidity.
} 
public-private partnership in favor of the State through the New Deal and the innovative regulation of the financial sector.

Remembering that at that time US banks could operate as de facto multifunction banks through their securities affiliates, Fisher's opinion that the primary cause of the systemic financial crisis was their direct or indirect overexposure to speculation must be considered in the context of the mounting condemnations of multifunction banking that finally led to the Banking Act of 1933, the so-called Glass-Steagall Act. ${ }^{17}$

The Glass-Steagall Act separated banking from finance, with banks not only restricted to the short-term segment of financial assets and liabilities, thus centered on short-term loans and the management of the payments system, but also being separated from nonbanks for ownership and management. ${ }^{18}$ Banks were also forbidden to pay interest on demand deposits and bound to a regulated maximum rate on time deposits. Deposits were insured within a ceiling by the newly created Federal Deposit Insurance Corporation (FDIC). ${ }^{19}$ Barred from commercial bank activity and from access to central bank's liquidity, investment banks were de facto confined to underwriting and to dealing with medium- and long-term finance.

\footnotetext{
${ }^{17}$ Kregel $(1996,2010 a)$ offers a fascinating reconstruction of the process that led to the Glass-Steagall Act. According to Kregel, the current interest in Glass-Steagall is justified by the fact that "the experience of the recent financial crisis, as well as those of previous history, suggests that it is multifunction banking that is the source of the crises" (Kregel 2010a, 49). What follows owes much to Kregel's analysis.

${ }^{18}$ Exceptions to not engaging in security dealings were bonds issued by the public sector and the granting of loans collateralized by securities to nonbank affiliates, however not exceeding 10 percent of the bank's capital for individual exposures, or 20 percent in total. Furthermore, the market value of such collateralization should cover 120 percent of the loan. We might wonder if the necessity of supervising compliance with the new rules induced the inclusion of the following provision at the beginning of the Act: "Each Federal reserve bank shall keep itself informed of the general character and amount of the loans and investments of its member banks with a view to ascertain whether undue use is being made of bank credit for the speculative carrying of or trading in securities, real estate, or commodities, or for any other purpose inconsistent with the maintenance of sound credit conditions; and, in determining whether to grant or refuse advances, rediscounts or other credit accommodations, the Federal reserve bank shall give consideration to such information" (US Congress, Banking Act 1933, 2; italics added). Having to judge the consistency of banks' operations with sound credit conditions and linking it to access to central bank's liquidity, a Federal reserve bank might have gone beyond requiring a simple quantitative compliance with formal rules, potentially prefiguring a never-adopted sui generis discretionary microprudential approach to bank supervision, where the threat of not accessing central bank liquidity would serve as a strong incentive against excessive risk taking.

${ }^{19}$ Suggestions to modulate the insurance premium on bank riskiness were neither included in the 1933 Act nor in the 1935 Banking Act, which mainly focused on making the Fed more responsive to the government's policy stance (Bradford 1935). Both acts also did not contain provisions on the FDIC's ex ante actions directed at the recovery of troubled banks.
} 
As Kregel highlights, although the Act profoundly affected the structure of the financial system, it was devised just as a set of stopgap measures to deal with the ongoing crisis. More time and further reflections were deemed necessary for a "completely comprehensive measure for the reconstruction of our banking system, such as been urged by some responsible men" (Senate Committee on Banking and Currency Report [1933], as cited in Kregel [2010a, 51]). The Act was in fact tailored on what were perceived as being the main causes and effects of the crisis: in particular, taking for granted that credit creation is pushed by its demand, the intent was to confine speculation to the securities market, and therefore not fostered by bank credit. Barred from speculation on private securities, banks were cleansed of one determinant of financial fragility. Even so, an Act that was seemingly based on the real bills doctrine (according to which short-term bank credit is considered safe because it only responds to decisions on current production) could not avoid that the dynamics of production and credit might continue to follow, although in weakened form, destabilizing paths due to the inherent instability of credit analyzed by the authors discussed in the previous section. But that was not the pressing concern in 1933, even if the international gold standard and its disciplining mechanism had already practically disappeared, because the postcrisis problem was how to promote an upward spiral of prices and production.

A relevant point raised by Kregel concerns the viability of the new financial structure, at least in the long period. Glass-Steagall granted banks the monopoly of creating liquidity by means of deposit creation and to nonbanks the monopoly of liquidity creation in the securities market. This means that the Act "did not give banks a monopoly on the creation of liquidity" (Kregel 2010a, 58). The condition of viability for the specialized structure created by the Act then rests on one form of liquidity creation not posing a vital competitive threat to the other. As Kregel argues, having an Act based the separation between banking and finance on forbidding dealing in specific types of assets and liabilities, a competitive threat on banks could come, and came, from the benevolent approach by the authorities and from legislation on nonbank financial innovations: "[T]he disintegration of the protection of member banks' deposit business was much due to the conscious decisions of regulators and legislators to weaken and suspend the protection of the Act, and to provide explicit support for the competitive innovations of nonmember banks, as it was to the triumph of market forces over monopoly. Indeed, it would be possible to argue that Glass-Steagall provided the unregulated investment banks with a 
monopoly over securities market activities that were functionally equivalent to the deposit business and liquidity creation of regulated banks" (Kregel 2010a, 60). With their viability threatened, banks pressed for a more competitive regulatory playing field by liberalizing their business model, which they gradually obtained, culminating in the final repeal of Glass-Steagall by the 1999 Financial Modernization Act.

A further limit to Glass-Steagall is given by the absence of any reference to US banks' international activities, directly or through affiliates, which had been granted by the Federal Reserve Act. As we will see later, it was then up to the supervisory authorities whether or not to extend the precepts of Glass-Steagall to banks' foreign operations, thus adding a further brick to the development of the second age of financial globalization.

To maintain a minimum viability to its structural design, the Act or subsequent legislation should have clearly defined the separation not in terms of instruments but in terms of the type of liquidity creation, for example defining "the business of banking as the creation of liquidity through the acceptance function of client liabilities. [...] All other forms of liquidity creationincluding market making, derivatives, structured lending, and credit-enhanced special purpose entities - would fall within the realm of investment banking. Here, expertise would be in arbitraging market imperfections; that is, risk, interest rates, exchange rates, and so forth. Under such a division, money market mutual funds, which effectively replicated the acceptance activities of banks, would have been a permissible commercial bank activity rather than creating competitive pressure" (Kregel 2010a, 71-72).

The half-baked Glass-Steagall solution worked in the short- and medium-term, but left room for longer-term financial structural instability; when the latter began to appear, it was left to gain momentum and finally it was dealt the "completely comprehensive measure" that abolished the Act.

The message sent in the 1930s by the US regulation of multifunction banking was not received by countries where the multifunction banking model was practically absent, as in the UK, or where capital markets were not developed, as in Germany. It was partially followed by Italy with its 1936 banking reform, which separated commercial banks from the Istituti di Credito Speciale 
(special credit institutions specializing in long-term loans funded by medium- and long-term debt). However, in Italy financial stability was de facto guaranteed by the nationalization of practically the entire banking system.

The different national financial regulatory responses to the crisis were just one of the many facets of the dissolution of the first age of trade and financial globalization in the 1930s. The end of the international gold standard and the rise of nationalism and isolationism produced not only beggar-thy-neighbor policies, which mainly affected exchange rates and trade tariffs, it also produced the beginning of a profound rethinking on the necessity of gaining national autonomy to make room for domestic policies directed at assuring social peace in a context where the model of liberal democracy was increasingly challenged by communist and fascist alternatives. ${ }^{20}$ For its theoretical and policy aspects, we have already mentioned the chapter that Keynes dedicated to national autonomy in his 1930 Treatise on Money. Keynes returned to the subject with more resolve in his 1933 Dublin Lectures on "National Self-sufficiency," in which he states that "I sympathize, therefore, with those who would minimize, rather than those who would maximize, economic entanglements among nations. Ideas, knowledge, science, hospitality, travel - these are the things which should of their nature be international. But let goods be homespun whenever it is reasonable and conveniently possible, and, above all, let finance be primarily national." 21 Indeed, these are the bases of Keynes's contributions to the discussions that finally led to the 1944 Bretton Woods Agreement.

In the midst of WWII, the American and British governments began discussing, with the aid of their economic advisors, a new postwar international order whose goal was to overcome the limits of the gold standard while avoiding the disruptions experienced in the 1930s through international political and economic cooperation. Looking from the perspective of the mid1940s, the design included the United Nations (1945), the international monetary order and

\footnotetext{
${ }^{20}$ See for example, Keynes (1936: ch. 24).

${ }^{21}$ See Keynes (1933, 167-68) for the full original version included in Emmett (2013). Although critical parts of Keynes's April 1933 Dublin Lectures were politically motivated by his effort to present a compromise in the thenraging conflict between the UK and the recently independent Ireland regarding the latter's policy toward selfsufficiency, exactly the same expression is to be found in the article with the same title published in June of the same year in The Yale Review $(1933,758)$. Keynes did not explicitly return to the globalization-protectionism issue in the General Theory, but the already-mentioned policy and social implications of his theory presented in chapter 24 require a significant degree of national autonomy.
} 
institutions as delivered by the Bretton Woods Agreement (1944), and the International Trade Organization. The latter was agreed on at the 1948 Havana Conference, but its charter was not ratified afterwards, so that it was the more limited General Agreement on Tariffs and Trade (GATT) - reached the year before in Geneva, that was later institutionalized and then converted into the World Trade Organization — that dealt with trade cooperation. ${ }^{22}$

Bretton Woods is normally considered as the final synthesis of the Keynes and White plans. However, to understand how far the final outcome was away from Keynes's original proposal, and to a lesser extent from White's, a detailed discussion of both is required.

Volume XXV of the Collected Writings of John Maynard Keynes contains four drafts of Keynes's proposal on the international clearing union (ICU), initially termed "international currency union." The fourth and final draft was inserted into the Treasury's Memorandum on External Monetary and Economic Problems. ${ }^{23}$

The nature of the ICU and the essential principles from which it is derived do not change in the various drafts. However, pressed by criticisms, Keynes abandoned the rigidity of a rule-based adjustment mechanism in the later drafts in favor of a discretionary one.

To render the objectives and mechanisms of the proposal clearer, I will follow the rule-based version. As it is well-known, Keynes's purpose was to allow a certain degree of external imbalances without draining liquidity from the system and inserting symmetric adjustments when large imbalances accumulate. The main features of the ICU may be summed up in the following points:

\footnotetext{
${ }^{22}$ The Havana Charter contained a chapter dealing with intergovernmental agreements on commodity control, aimed at containing the frequent and wild fluctuations of international commodity prices driven by speculation. The provisions contained in that chapter were hardly followed in the agreements negotiated in the postwar period. Since the stabilization of commodity prices was seen as strictly linked to the international monetary arrangement and to the effectiveness of domestic macroeconomic policies, for the Havana Charter, this issue owed much to previous US and UK initiatives. For the role of Keynes, Harrod, and Robertson as experts for the UK on commodity stabilization schemes, see Moggridge (1980b: part I).

${ }^{23}$ The drafts are dated September 8, 1941, November 18, 1941, December 15, 1941, and January 25, 1942. See, Moggridge (1980a: ch. 1). The final draft, issued by the British Government in April 1943 as a white paper, is reproduced in Horsefield (1969, 19-36).
} 
a) An international clearing bank (ICB) is created and all international transactions are cleared through the central banks of member countries operating on their accounts with the ICB.

b) Within any member country, the provision of foreign exchange is concentrated in the hands of the central bank, on whose authorization all capital flows depend.

c) Private and public international transactions may occur only if approved by the authorities on both sides of the transaction.

d) National currencies have a fixed, but adjustable, value with respect to the ICB's unit of account, called bancor, whose value is fixed in relation to its gold content. Bancor could be acquired in return for gold, but gold could not be acquired in return for bancor.

e) For each country, an index quota (IQ) is computed as one-half of the past average sum of exports and imports.

f) For each country, the ICB computes the total net credit or debit position. If the positive or negative imbalance is higher than one-quarter of the IQ, the creditor (debtor) country is allowed to revalue (devalue) with respect to bancor up to 5 percent per annum. If the imbalance is higher than half of the IQ, the country is obliged to revalue or devalue up to 5 percent per annum. If the credit position is higher than the IQ, the excess is transferred to the ICB's reserve fund.

g) On debit and credit positions exceeding one-quarter of the IQ, interests are paid, at a rate that increases with the level of the imbalance. Credit positions lower than one-quarter of the IQ do not receive interests. All interests are transferred to the reserve fund.

h) Creditor or debtor countries may withdraw from the Union, in which case their positive or negative balances are transferred to the reserve fund. 
Summing up, while the current account of the balance of payments would be liberalized, preventive controls of capital movements (although not their prohibition) should avoid speculative flows and, more generally, excessive external imbalances with respect to trade balances. Physiologically, imbalances should mainly reflect trade imbalances, which, if relevant and persistent, would call for exchange rate adjustments. ${ }^{24}$ Allowing noncollateralized overdrafts, the multilateral clearing and settlement system permits limited imbalances to persists. When negative or positive imbalances tend to accumulate above safe limits, first symmetrical dissuaders come in as interest payments, while final adjustments eventually require exchange rates variations. The aim is to avoid defensive actions from debtor countries that normally imply deflationary policies, which, in the end, harm creditor countries, too. Keynes's position is clearly expressed in an amendment that he formulated to meet the opposition of Labour Minister Ernest Bevin that was afterwards approved by the War Cabinet. It states that a debtor county's request to the ICB's governing board to improve its position should not "include a deflationary policy, enforced by dear money and similar measures, having the effect of causing unemployment; for this would amount to restoring, subject to insufficient safeguards, the evils of the old automatic gold standard" (Keynes in Moggridge 1980a, 143). Finally, in the course of time, the reserve fund would accumulate resources, which, acting as ICB capital, could absorb losses if a debtor country were to exit the Union and declared in default, or could be used to help member countries hit by extraordinary events.

The plan proposed by Henry Dexter White substantially differed in nature from Keynes's clearing union, notwithstanding relevant common goals and features (White 1943). The plan envisioned the creation of a Stabilization Fund (Fund hereafter) whose resources are the quotas paid in gold, national currencies, and securities of member governments; these resources "would be available under adequate safeguards to maintain currency stability, while giving member countries time to correct maladjustment in their balance of payments without resorting to extreme measures destructive of international prosperity" (White 1943, 86). Member countries' exchange rates would be fixed, allowing oscillations within a permitted band, in relation to the Fund's notional monetary unit (called "unitas"), whose value would be determined by its gold

\footnotetext{
${ }^{24}$ Although the main adjustment mechanism of the plan refers to the exchange rate, mention is also made of trade agreements among countries containing clauses allowing temporary restrictions when their respective clearing accounts satisfied the agreed upon criterion.
} 
content. Transactions concerning the current account of the balance of payments would be liberalized. The exchange rate could be adjusted to correct a fundamental disequilibrium that would predominantly concern the current account. This required that member countries could adopt restrictive measures upon capital transfers with cooperation at both ends. ${ }^{25}$ Absent a clearing system possessing a monopoly on currency transfers among member countries (as envisaged in Keynes's plan), private clearing and settlement markets would exist, albeit member countries operating in them should not undermine the stability of the exchange rates established by the Fund in doing so.

After long discussions between Keynes and White during the period between SeptemberOctober 1943, and subsequent extensive redrafting, a "Joint Statement by Experts" on the establishment of the now-renamed International Monetary Fund (IMF) was published in April 1944, constituting the preliminary discussion document at the Bretton Woods Conference. The final outcome was the IMF's “Articles of Agreement," approved at the end of the conference on July 22, 1944 (Horsefield 1969, 185-214). The White approach prevailed, augmented by the reference to the dollar convertibility into gold at a fixed price, which was the basis for converting the system into a dollar exchange standard. The explanatory notes by the British experts prefacing the "Joint Statement" and the "US Commentary" on the same document (Horsefield 1969) not only tried to mask the UK's defeat - where the UK document asserts that the Fund and the currency union are "two arrangements [that] represent alternative technical setups, capable of performing precisely the same functions" (Horsefield 1969, 129) — but it also conceals deep disagreements inside both camps.

It was rather clear to all interested parties that the goal of ensuring national autonomy, asserted by Keynes and White, politically meant accepting not only the public command over international finance but also Keynes's interventionist policies in the United Kingdom and

\footnotetext{
${ }^{25}$ On capital controls, the changes from Keynes's and White's 1942 drafts to their 1943 ones were affected by the large US banks' opposition to limiting their international scope, which will be discussed later. According to the White plan, the obligation of capital controls to be exercised at both ends of the $1942 \mathrm{draft}$ was converted in the 1943 draft into voluntary cooperation, while Keynes's 1943 draft, aware that the United States would not adopt capital controls, left the decision on their adoption to individual member countries while asserting that "[s]ome less drastic way might be found by which countries, not themselves controlling outward capital movements, can deter inward movements not approved by the countries from which they originate" (in Horsefield [1969, 31-32]). Although both White and Secretary of the Treasury Henry Morgenthau had previously clearly expressed their opposition to speculative capital movements, as we shall see, the final agreement was rather weak in this respect.
} 
Roosevelt's New Deal in the United States. However, the British Treasury and the Bank of England had not sensibly moved away from their pre-Keynesian fiscal and monetary approach. In particular, the Bank's preference went to a scheme based on two dominant currencies (the US dollar and the pound sterling), for which the existence of neither the clearing union nor the Fund was necessary, and orthodox - gold-standard type-policies would dominate. Given the weak UK financial situation due to the war effort and the desire to protect both London as an international financial center and the role of the pound sterling, de facto the Bank only shared Keynes's position on the necessity to control capital movements, at least as a temporary postwar expedient. In the US camp, the position of the Treasury (White and Morgenthau) and of the supporters of the New Deal was strongly opposed by the large US banks, who fiercely fought against both the Fund's creation and the insertion of capital controls into the agreement. If the United Kingdom won the battle by inserting the right to use capital controls, US banks won the war by obtaining eliminating the obligation for coordinated action. ${ }^{26}$ To explain the relevance of this point, let us summarily go back to the alternative solutions.

According to Keynes, finance should have remained substantially national, empowering central banks with full control of capital flows. The aim was twofold: first, to limit the capital flows to sustainable foreign direct investments (FDIs), thus avoiding the speculative movements that had forced country after country to exit from the gold standard in the 1930s, disrupting exchange rates and international trade; second, to reduce balance of payments imbalances to current account deficit or surplus net of FDIs, thus making the exchange rate effective as an adjustment mechanism for structural imbalances. In addition, any international flow, whether coming from trade or FDIs, necessarily had to be cleared through the ICB, thus eventually putting in motion its adjustment mechanisms. Private international finance would have been thus spoiled of both speculative activity and the intermediation of country imbalances.

On the contrary, the "Articles of Agreements" as approved at Bretton Woods left a potentially significant role for international private finance. Countries could resort to private finance up to

\footnotetext{
${ }^{26}$ A narrative in this direction is offered by Helleiner (1994: ch. 2). The prevalence of US banks' position may have been also determined by the firm intention of the US government to affirm the supremacy of Wall Street and to dissolve the sterling bloc, thus also favoring US exports; see de Cecco (1979). As Rauchway (2015) shows, the opposition of large US banks to Roosevelt's policies marked all the years of his presidency and continued after his death in the attempt to impede congressional approval of the Bretton Woods Agreement.
} 
the limit of not putting their exchange rate in peril-a rather ambiguous concept also devoid of operability given the absence of countervailing measures. Although a country could enter swaps with the Fund to acquire foreign currencies, this was subject to a cost that would increase with the excess of its currency held by the Fund with respect to its quota and, more relevantly, subject to "adequate safeguards" (later institutionalized as the Fund's conditionality), among which was the prohibition on using resources conceded by the Fund to finance sustained capital outflows. Here is where the control of capital flows comes as a constraint. The fact that article VI of the Fund's statute includes the possibility for countries to adopt capital controls as defensive measures means that the system is based on the free circulation of financial capitals and not on controlling capital movements as the foundation of the ex-ante balance of payments management. More generally, only the public, centralized control of capital flows could circumscribe the current account imbalances for which the adjustment mechanisms were thought. In addition, because the effectiveness of capital controls depends on global cooperation and requires the concerted action of countries at both ends of capital movements, the US banks' success in converting this cooperation into only a voluntary one paved the way for private finance to regain its international dominance. ${ }^{27}$ Moreover, with the cost of adjustment mechanisms only weighing on deficit countries, incentives to deal exclusively with the Fund were weakened. ${ }^{28}$ In other words, the Fund was the lender of last resort, but not necessarily the lender of first resort, and the flexibilities and incentives left to member countries could potentially recreate the conditions for increased international instability and consequently more frequent last resort interventions by the Fund. As subsequent developments have also shown, the opinion that Bretton Woods was opposed to free financial capital flows has more solid foundations if we refer to the spirit rather than to the letter of the accord. As it was drafted, the

\footnotetext{
${ }^{27}$ White asserted at a press conference held at Bretton Woods that the United States did not wish to adopt capital controls (Helleiner 1994, 49). The European balance of payments difficulties that culminated in the 1947 crisis well illustrates the point. Together with trade deficits, the main cause of those difficulties was the illicit flow of European capitals that fled from European economic and political instability, ending up in the US banking system. US banks successfully pressed their government not to cede to the European governments' repeated requests for assistance, not even by means of soft measures, such as sharing information with the countries of origin. Although the Marshall plan de facto compensated for the outflows, the same phenomenon reappeared in the subsequent years (Helleiner 1994: ch. 3). Keynes's plan, with the strict controls by central banks and the obligation of cooperation outlined in its first drafts, would have limited capital outflows at least to distorted invoicing of imports and exports.

${ }^{28}$ The only safeguard came from the preoccupation that after the end of the war the dollar could become a scarce currency (article VII). However, this did not refer to the dollar becoming scarce for one or few countries; anyway, failing to convince the scarce-currency country to take remedial actions, the only last resort defensive action was to permit the other member countries to use import limits, thus going against the general assertion that adjustments should not produce deflationary effects.
} 
statute of the IMF allowed the liberalization-oriented approach to soon appear and then to prevail without necessitating a change of the letter.

Lastly, the two approaches possessed different types of nonviability. As a gold-dollar standard, the Bretton Woods system was exposed to the Triffin liquidity dilemma versus the convertibility dilemma, according to which, in absence of a commensurate increase in gold production, the increasing demand for international liquidity and reserves would have required US balance of payment deficits, thus decreasing the US's ability to fulfil its convertibility obligation. Doubts about its sustainability should also have come from the historical difficulties of managing the sterling-based gold standard without active cooperation from other major financial centers when international private finance was left free to operate, and from the necessity to favor the viability of the system with respect to domestic interests in the American type of democracy. On the other hand, the original Keynes plan was politically nonviable from the start because it implied that all countries would have been treated with complete economic and political symmetry.

\section{THE SHORT INTERREGNUM}

The end of the first of our two ages of financial instability in the 1930s produced reactions leading to the assertion, both on theoretical and policy grounds, of a new active role for national States and of their international cooperation. An international order was sought to produce a sort of "soft" globalization, in which the combination of cautious trade openness with limits imposed to international finance would have permitted sustainable forms of national autonomy. In some instances, the goal of financial stability was pursued at the national level with innovative structural and prudential measures of financial regulation. The question is whether the Bretton Woods interregnum, lasting until the early 1970s, can be thus properly characterized.

As we have seen, financial and economic interests, helped by national interests and by the difficulty of abandoning "old" beliefs, had weakened Keynes's and White's internationally coordinated "statist" approach. For what most concerns us here-although the debilitated political reach of finance prevented the large US banks from dictating their entire agenda, which would have guaranteed private finance was the sole source of postwar international 
intermediation - they were nonetheless capable of preserving their potential comeback. The solutions adopted in the early 1940s were, for a time, effective but had limits and weaknesses that were late to manifest their effects due to a series of factors.

First, due to defaults on international public and private debts in the early 1930s, the abandonment of the gold standard, the fall of international trade, and widespread capital controls, international private finance had nearly collapsed, while the management of WWII put most international finance in public hands. Nonetheless, private financial interests were far away from being definitely out of the game.

Second, it took several years for most belligerent countries to manage their economic reconstruction to the point of being able to comply with the Bretton Woods rules, as it was for the opening of their current account, adopted in 1958 by most Western European countries. However, absent a Keynes-type system of coordinated current account adjustments, international imbalances soon accumulated, pushing some countries (especially European ones) into retaining capital controls, ${ }^{29}$ but giving ammunition to banks for regaining their international role and raising doubts about the sustainability of fixed exchange rate regimes. Although the formal liberalization of the capital account — which, according to our interpretation, was implicit in the Bretton Woods Agreement - took further decades (for most developed countries, beyond the Bretton Woods period), the benevolent attitude of some national authorities toward the interests of their financial firms rendered capital controls ineffective and allowed a string of financial innovations that began to produce short-term capital flows, further eroding the effectiveness of capital controls where they were adopted.

The main example of this was the birth and expansion of the London eurodollar market since the mid-1950s. Although several factors explain the demand for and supply of dollar-denominated deposits in UK resident banks, the will of the British authorities to maintain London as an international financial center allowed the first relevant financial innovation post-WWII in the form of the eurodollar market. ${ }^{30}$ In 1962, the Bank of England authorized the issue of securities

\footnotetext{
${ }^{29}$ Either on capital inflows or outflows, due in part to their balance of payment position.

${ }^{30}$ The UK government's initial doubts about allowing short-term speculative capital movements were overcome by the Bank of England's assertion that the city's international role required free capital movements for nonresidents. An analysis of the first developments of the eurodollar market is presented by Schenk (1998) and Burn (1999).
} 
denominated in foreign currencies; the growth of the eurobond market thus transformed the eurodollar market into a full-fledged international capital market (Helleiner 1994, 84-89). The US authorities, too, kept a benevolent attitude toward these developments in this period. With the Federal Reserve Act allowing international operations by US banks (Kregel 1996, 93), at the end of 1962, the latter (left free of some limits and costs imposed domestically) already had the largest share of eurodollar deposits (Schenk 1998), enlarging their scale of operations after the Fed's 1966 credit squeeze and the US adoption of capital controls that posed limits to US resident banks' ability to grant loans to foreigners in other foreign assets (Gibson 1989: ch. 1; Kregel 1996, 106). ${ }^{31}$

Significantly, the post-reconstruction years of the Bretton Woods period were characterized by frequent balance of payments difficulties, with the retention or adoption of capital controls driven by current account imbalances and/or by speculative financial flows. Absent strict international cooperation on capital movements and symmetric adjustment mechanisms, longterm capital movements and short-term speculative flows flourished irrespective of what external balances would have required, reducing the degrees of freedom in national policies - just what the accord was initially meant to avoid. When national deflationary policies were adopted, recourse to the international eurodollar market offered an escape for financial and nonfinancial firms. Even if the gradual return to a framework marked by potential financial fragility was partly concealed by the high growth rates favored by resurgent international trade, these developments were hardly what Keynes and White originally had in mind.

Even if the development of the eurodollar market affected the liquidity and solvency of some financial firms (Schenk 1998, 236), the Bretton Woods period was not characterized by relevant financial crises, strictly defined. The reviving international finance had not yet reached the size or incorporated features necessary to be a leading factor of international or domestic financial instability.

\footnotetext{
31 This attitude was later reversed in 1981 when, in order to keep the US domestic financial market competitive, the Fed permitted the establishment of international banking facilities (IBFs) in the United States, so that non-US residents could conduct banking transactions in the United States free of any reserve requirements, interest rate limitations, and without the cost of being insured by the FDIC (Terrel and Mills 1985).
} 
This also because the management of postwar reconstruction in many countries prolonged a structural approach toward the financial system for attaining general policy goals. Especially in Continental Europe, strict operational controls or public ownership of financial firms was seen as a necessary ingredient for mending the wounds left by the war and for cautiously inserting the countries in the new international context. Beside controls on international capital flows, ceilings on interest rates for loans and deposits, restrictions on the dynamics and composition of bank assets, liquidity, and reserve requirements had the intended, or unintended, effect of smoothing the "inherent instability" of credit. In the United States, the weakening of GlassSteagall due to the authorities' acquiescence to financial innovation had not yet started and up until the demise of Bretton Woods, the Fed was able to keep financial cycles under control, also by means of structural measures (Kregel 1996, ch. 4).

The relative financial stability of the Bretton Woods period was thus linked to the inheritance of the 1930s and to the difficulties in managing the postwar period, which were limiting the degree of financial globalization. But its endogenous dynamics, helped by the increasing political influence of financial interests left open by the Bretton Woods Agreement, were in the direction of a steady increase of international finance.$^{32}$ In reality, Bretton Woods did not mark a decisive and permanent change of the dominant theoretical and policy paradigm. The statist approach of Roosevelt, White, and Keynes - which also required submission of finance to domestic welfare objectives - had always been opposed not just by the formidable interests of private bankers and by central banks, but also by a plethora of economists and officials who did not abandon their "old belief" in orthodox policies and the laissez-faire paradigm. On the theoretical side, what later was to become a counterrevolution had already started in the 1940s, led both by neo-Pigouvians dressed as Keynesians (like Modigliani) — in which lip service was paid to uncertainty, the validity of Keynes's theory was limited to short-term phenomena, and the justification of his policies only derived from rigidities in the labor and goods markets

\footnotetext{
${ }^{32}$ Helleiner (1994) argues that the progressive return to global finance was the result of actions and inactions by the governments of the main developed countries, particularly the UK and US, which, although being able to do so, did not stop financial innovations leading in that direction. As for Kregel's analysis of the gradual debilitation of GlassSteagall, much of Helleiner's narrative on governments' responsibility can be agreed upon. However, similarly to the Glass-Steagall legislation, we have argued that the Bretton Woods Agreement was not consistent with the original ideas of its promoters. Capital controls were allowed as defensive measures, while the physiology of the system was the liberalization of all capital flows. As we have seen, this represented White's capitulation in the face of the pressure from US banks.
} 
(Roncaglia and Tonveronachi 1985) — and, on the "neoliberal" front, by Friedrich Hayek and Milton Friedman, helped by increasing private funds directed at universities and think tanks to foster laissez-faire-inspired research and the dissemination of their ideological and policy implications (Tonveronachi 2018; Roncaglia 2019: ch. 8). On the policy side, private finance was steadily reasserting its political influence in the US and the UK, which possessed the world's leading financial centers. While the immediate postwar international and national designs would have needed a later reassessment in the direction of a coherent statist approach to avoid a return to the instability of the previous age, a resurgent laissez-faire design was steadily taking hold, leading in the opposite direction. Despite the absence of full-blown financial crises, the Bretton Woods period cannot therefore be considered either as a tranquil interlude or as presenting consistent and widely accepted international and national financial designs purporting long-term financial resilience.

\section{THE POST-BRETTON WOODS'AGE OF FINANCIAL INSTABILITY}

The institutionally creative period immediately following WWII is often considered as the affirmation of international political and economic cooperation, producing a rupture with the nationalisms of the previous period. Looking at the process leading to Bretton Woods and at the failure of the International Trade Organisation, in reality what we observe is that the US and UK negotiated between themselves what type of cooperation to impose on the rest of the world. Understandably, the solutions were the result of their prevailing vision of the future and were permeated with the affirmation and defense of their national interests. ${ }^{33}$

The efficacy of the watered-down version of the original Keynes and White plans written into the Bretton Woods Agreement was dependent on the voluntary coordination among member countries for symmetric adjustments and capital controls. Its success would have allowed significant, although delimited, degrees of autonomy for national objectives and policies. The demise of Bretton Woods came from failing on this front, especially with the gradual shift toward a dollar-based system, because voluntary cooperation did not prevent national interests

\footnotetext{
${ }^{33}$ However, at the end of the story, UK interests followed the fate of the other countries.
} 
from prevailing on the objective of international stability. At the end of the 1950s, "fundamental flaws in the [Bretton Woods] arrangement began to appear. The US balance of payments was deteriorating markedly, undermining the US commitment to maintain its official gold price. By 1961, total external US dollar liabilities exceeded the US gold stock, which encouraged foreign central banks to convert unwanted dollars into gold, heightened uncertainty about the entire currency grid, and fostered speculative flows" (Bordo, Humpage, and Schwartz 2011, 2). The final blow came from the expansion of US public expenditure linked to the Vietnam War and to Lyndon Johnson's Great Society programs.

The US's 1971 decision to abandon the gold-dollar convertibility, which prompted the end of fixed exchange rate regimes, and the failed attempts to reach some new effective form of cooperation inexorably led the international framework toward the liberalization of movements of financial capital and financial firms.

The first oil shock of 1973 acted as powerful catalyst to this dynamic due to the large external imbalances it created between oil producer and consumer countries. For the IMF to cope with them, and with the changes that in the meantime had affected the world framework, its charter should have been radically revised regarding, first of all, its resources and operations. Two main decisive obstacles impeded this solution. First, the US resistance to weakening the role of the now-inconvertible dollar as the dominant reserve currency in favor of the de facto extension of undercollateralized loans through the very large emission by the IMF's Special Drawing Rights that was required by the circumstances. Second, private finance, now supported by the revival of the radical version of laissez-faire and having recovered significant political influence, now had the weapons to finally make headway in the war on international financial liberalization that it had begun against the role of IMF during the final phase of the Bretton Woods negotiations.

Private international finance then took charge of the management of petrodollars, becoming the prevailing lender of first resort for private and public debt, leaving the IMF to deal with crisis situations. Consistent with the new framework, since the 1970s we observe the tendency toward the progressive general shift of countries to open the financial account of their balance of payments. 
One repercussion of the end of Bretton Woods, of the petrol-imbalances, and of the shift from IMF to private finance was the proliferation of risks in international finance. On the demand side, while the IMF's credit is conditioned to the adoption of unpopular deflationary policies in order to be repaid, the absence of such conditionality for private credit weakened the discipline of governments' demand for foreign funds. Furthermore, absent a coordinated approach, given the plurality of suppliers of foreign funds and the shorter time horizon produced by the increased uncertainty of the period, the private sector's foreign position also escaped from the evaluation of long-term lending sustainability at the country level. On the supply side, beside new (or enhanced) market risks, sovereign risk again made a significant appearance on the balance sheets of financial firms.

The post-Bretton Woods period can be summarily analyzed following three main connected trends pointing to: the redesign of the State's role and the nature of its policies; the quantitative and qualitative explosion of national and international financial deepening; and changes in the nature and scope of financial regulation and supervision.

The policy implications derived from fiat money overcoming the constraints posed by gold reserves is a useful way to introduce the first trend. While financial openness and flexible exchange rates were in full accord with the emerging laissez-faire movement, the new monetarists saw a serious threat to monetary stability in the freedom gained by central banks and governments. Supported by the stagflation of the 1970s, the push toward making central banks independent and constraining them with rules, such as Friedman's golden rule or inflation targeting, gained traction.

The above is a relevant example how the new theoretical and policy paradigm gives primary relevance to the distorted incentives that influence the actions of governments, bureaucracy, and politics, and to the need to drastically reduce their scope and to pursue market-friendly policies. ${ }^{34}$ Briefly, the State should abandon its direct involvement in economic matters to become just the arbiter on compliance with market-friendly rules. As a consequence, the public sector had to be structurally "crowded-out" by liberalized markets, which required the dismantling of its direct

\footnotetext{
${ }^{34}$ The reference is to the theory of public choice, developed beginning in the 1960s; see Buchanan and Tullock (1962).
} 
interventions and participations in the economic sphere. The new international and national paradigm thus required the abandonment of the prominence given to cooperation and public intervention for assuring stability and national welfare, in favor of economic freedom that would permit markets to bring competition and efficiency that were thought to be the ephors of longterm growth and stability. In such a self-adjusting scheme, governments are bound by the same logic followed by private entities and Keynes's problem of the necessity of national autonomy to pursue welfare goals does not exist.

The data and analyses presented by Schinasi (2007), Borio (2007), and UNCTAD (2009) help to give substance to the second trend. The post-Bretton Woods period is characterized by a massive increase of financial deepening only due to nonmonetary assets (securities and derivatives), by increased complexity both at the financial firm and system levels, and by the increased size and internationalization of financial firms. The latter is not secondarily due to the increase in current account imbalances, more notably since the late 1990s, which shows the failure to deal with global imbalances at the national level. ${ }^{35}$ The explosion of Schinasi's inverted pyramid of finance in the last fifty years is predominantly the result of the explosion of leveraging debt and liquidity - to a large extent due to contracts internal to the financial system - in what Fisher calls the "pyramiding of debt" and Minsky calls "financial layering” (Minsky 1986): on a small amount of primary and secondary liquidity, a large pyramid of leveraged market and over-thecounter positions is built, whose liquidity depends on the validation of expected asset prices. We have seen that Marshall, Hawtrey, and Fisher had already exposed the instability of such construction. When expectations of financial asset prices are not validated and a large injection of better (primary and secondary) liquidity is not fully and readily available, ${ }^{36}$ while the enormous size reached by the upper layers renders such injection problematic (as testified by the recent crisis), the upper layers of the inverted pyramid implode producing what Avinash Persaud (2002) calls "liquidity black holes." In terms of Minsky's theory, financial layering has increased the share of actual and potential speculative and Ponzi positions, with repercussions for the

\footnotetext{
35 These external imbalances would not disappear even assuming orthodox adjustment mechanisms also because they follow from a deep and uncoordinated globalization that has produced a structural polarization between countries that are the "bankers of the world" (US and UK) and countries that are the "workshop of the world" (German Europe and East Asia) (Kalinowski 2011,4).

36 This in part due to the double filter for accessing a central bank's liquidity, represented by the typology of financial firms that can access its discount window and the assets accepted as collateral.
} 
overall margin of safety and the financial fragility of entire system. ${ }^{37}$ The systemic relevance of this new financial structure, which also sees nonpatient funds substituting for individual investors or traditional universal banks, is captured by Minsky and speaks of a new stage - that of money-manager capitalism. ${ }^{38}$

The relative size, complexity, and transformation of post-Bretton Woods global private finance has probably no historical antecedents, well outstripping those of our first age of financial globalization. Differently from what was promised as an alternative to Keynes's plan, global finance has not delivered in terms of national autonomy. Especially in peripheral countries, it has constrained the quest of domestic welfare goals, ${ }^{39}$ not least due to the creation and dissemination of international standards as the ones concerning the financial regulatory sphere.

Financial regulation and supervision have followed a path coherent with the balance of power between the State and markets outlined by the first trend, allowing the dynamic path analyzed by the second trend. As we have seen, the renewed political pressure by big private finance finally won over the initial hesitations by the UK and US on strengthening their national capital markets as international champions, allowing the development of the London eurodollar market, pushing for the liberalization of international capital movements, and permitting US resident banks to operate with the same modalities and regulatory benefits as in the eurodollar market.

In the same period, although in different ways and with different timing due to specific inherited situations, nearly all countries followed the same liberalization process that, in the United States, led to the progressive neutralization of Glass-Steagall and to its final elimination (see section 3, above). In the banking sector, structural measures, such as the specialization on risk taking and limits to asset growth and interest rates, disappeared, replaced by the new micro-approach

\footnotetext{
${ }^{37}$ Minsky borrows the term "margin of safety" from Fisher, who defines it as a shock absorber mainly based on the current structure of the balance sheet (see before section 2 in this paper). Beside this notion of current or short-term margins of safety, in Minsky's forward-looking theory of financial fragility, based on expected net cash flows of different financial structures, an expected margin of safety can also be defined as the present value of their cash flows net of debt service, thus measuring the expected distance from experiencing future funding and solvency problems. The expected margin of safety is thus prone to overvaluation and undervaluation, and hence subject not to be validated. The overvaluation of the expected margin of safety during a protracted expansion helps explain Minsky's dictum that stability is destabilizing (Minsky 1992, 7).

${ }^{38}$ See Minsky (1986 and 1991). The US evolution toward money manager capitalism and its consequences are discussed by Kregel (2010a) and Wray (2011).

${ }^{39}$ See UNCTAD (2019: ch. II) and the literature there referred to.
} 
derived by market practices according to which the freedom to assume any type and quantity of risk must be mitigated by hedging them, either entering derivative contracts or, finally, by the appropriate amount of own capital. As testified by the numerous revisions of the Basel Accord, the final task of regulators has become to apply what they consider to be the industry's best risk practices, eventually strengthened with prudential add-ons, while supervisors monitor their application and eventually add further prudential measures. Although some capital buffers were introduced to make room for macro-risks, bank regulation remain solidly founded on the measurement of micro-risks. The same applies to liquidity requirements introduced by the latest Basel release.

While apparently based on rules, microprudential bank regulation is largely based on discretionary decisions related to the definition of capital, its minimum amount, several parameters that differently affect the different models applied to banks with different systemic footprints, ample supervisory discretion, and so on. As a result, the outcome crucially depends both on the possibility of correctly pricing risks and on the distortions that are added or smoothed by applying discretion.

The push to adopt the above approach to banking regulation came from the increasing problems linked to the internationalization of finance. The first Basel Accord only referred to banks with relevant international operations in order to create a level international regulatory playing field and to stop the secular decline of their capitalization. However, adding national differences in accounting standards to the previous margins of discretion and to the absence of an international authority with effective implementation powers, national authorities retain ample room of maneuver so that the system is necessarily more discretion-based than rule-based, and the regulatory and supervisory playing field is strongly unlevelled. ${ }^{40}$ Furthermore, a dynamic tendency to converge toward less stringent standards is observable, while financial innovations circumvent the evolving rules, with the result of rendering weak implementations even weaker.

Minsky helps us understand the structural limits of this micro-based approach to capital regulation. Given that in the long run bank assets' rate of growth depends on the ratio of retained

\footnotetext{
${ }^{40}$ For a more extended discussion of Basel regulation and the international level playing field, see Tonveronachi (2018).
} 
profits on capital, it comes to depend on the return of assets, leverage, and the retention ratio. The Basel methodology tends to put a ceiling on leverage irrespective of the other parameters. The result may be that bank's assets growth is higher or lower than potential nominal GDP growth, producing either an increase of financialization or a constraint on real growth. Fundamentally it is not recognized that it is good bank profitability that is the functional source of future well-capitalized banks. In practice, regulation and supervision go in the opposite direction, subjecting banks to unfair competition from nonbanks and burdening them with high compliance costs, also related to liquidity and resolution requirements. As far as banks circumvent Basel capital requirements, they obtain higher asset growth based on high leverage and modest profitability, a very fragile mix. ${ }^{41}$

Regulation of nonbanks was, and still substantially is, limited to disclosure requirements. Ironically, after the elimination of forced specialization, financial regulation continues to be structured according to predefined categories of financial firms, instead of treating risks homogeneously wherever they are borne. This has led to an unlevel playing field between increasingly regulated banks and tenuously regulated nonbanks, with the expansion of the socalled shadow banking sector, which is not secondarily responsible for the second trend (concerning the explosion of finance) analyzed before.

In the same way in which the new global monetary and financial framework lacks an international authority guided by rules on managing external imbalances, exchange rate adjustments and capital movements, financial regulation, and supervision lack an international authority with effective power for rule implementation and with a comprehensive view of the financial system. In both cases, voluntary cooperation is called on, with the limits experienced in the last decades, and made even more evident after the 2007 crisis as shown by the scarce efficacy of the G20 and G10 policy deliberations and by the weak regulatory and supervisory reach of the Financial Stability Board and IMF's financial sector assessment programs (FSAP). The impossibility of building global authorities entrusted with the necessary political power renders the entire system critically dependent on the automatic adjustments advocated for by

\footnotetext{
${ }^{41}$ Especially when banks obtain high leverage by shifting their operations toward the trading book, which commands lower capital requirements than the banking book. For an extended treatment of these issues, see Montanaro and Tonveronachi (2011).
} 
laissez-faire theorists, whose action should be strong enough to also overcome both the nonconvergent interests and policies of powerful national and regional actors and their muddling with supposedly market-friendly rules. With respect to the real world, the latter just adds to the irrelevance of the hypotheses on which laissez-faire theories are built.

The picture that can be obtained comparing the two ages of global finance - the first with prevalent aristocratic tones and the second supposedly liberal—shows the post-Bretton Woods period is characterized by exploding financialization accompanied by increasingly pervasive regulatory attempts to deal with private developments that have been left free to mold the financial structure. The contrast with the first age of globalization, when financial regulation and supervision were practically nonexistent, is made even more significant by the second age being characterized by a chain of increasingly numerous, connected, and socially costly idiosyncratic, systemic, and global financial crises, despite the apparently sharp-eyed regulation and active fiscal and monetary weapons that have been often generously employed. ${ }^{42}$ The increased frequency and deepness of financial crises in the last decades testifies to how much the complex structure derived from the process of domestic and international liberalization/financialization has increased the endogenous Minskyan process of fragility's accumulation. To put the entire blame on regulators and supervisors would not be generous, since they follow the adopted international and national laissez-faire approach with coherence, at times trying to put limits to its "excesses." As we have argued in the introduction, in a capitalist economy, the public-private partnership requires that the State act as the guarantor of last resort for the private financial system's viability. Experience shows that the laissez-faire approach to finance creates conditions that make it excessively difficult and socially costly for the State to comply with this structural obligation.

A further comparison leads to interesting suggestions. Contrasting the two ages of financial instability with the Bretton Woods period may led one to suppose that the limited degree of freedom left by the latter to global and national private finance, although due more to special circumstances than to design, might have been responsible for its scarce episodes of financial

\footnotetext{
${ }^{42}$ A comprehensive and updated database of financial crises does not exist. For partially different phenomena and periods see BCBS (2004), Lo Duca et al. (2017), Laeven and Valencia (2018), Reinhart and Rogoff (2009), and UNCTAD (2015).
} 
instability. However, this same experience opens the question on the conditions that are required for a cautious financial globalization not being endogenously converted into overglobalization.

\section{CONCLUDING REMARKS}

Looking at financial instability, for at least four decades we have faced a situation that is more challenging than the one against which Keynes was reacting at the beginning of the 1930s with his statement that finance should be kept strictly national. Coherently, in the following years, on theoretical and political grounds, he developed an approach based on the State's active intervention directed at assuring the degree of national autonomy that would permit the attainment of a level of domestic welfare that he considered necessary for reformed democratic capitalism to survive the competition coming from authoritarian regimes. His draft for an international clearing union was the completion of his statist approach at the international level.

Keynes $(1936,384)$ notoriously affirmed that "soon or late, it is ideas, not vested interests, which are dangerous for good or evil." Our narrative shows that even more dangerous, for good or evil, is when ideas and vested interests take the same side. It was financial vested interests supported by "old" ideas that weakened the Bretton Woods Agreement up to the point of leaving the door open for its later demise. It was global financial and nonfinancial vested interests supported by "new-old" ideas that shaped the international post-Bretton Woods framework. It was the communion between financial vested interests and laissez-faire ideas that led to the sector's liberalization, as well as the progressive weakening and finally the end of Glass-Steagall and any form of structural regulation in favor of a system substantially based on self-regulation. The exclusion of Keynes's statist approach from orthodoxy came from the new dogmatic theology of laissez-faire cultivated by national and regional economic and political vested interests, not from technical weaknesses, which would have been more easily remediable.

The reaction to the string of crises that have littered the path of the post-Bretton Woods period show how entrenched global private interests and laissez-faire ideas are. As data show, finance is now as big and fragile, if not more than, as it was prior to the last global crisis. As the thenpresident of the newly relabelled Financial Stability Board declared that any financial reform 
should not, and in fact have not, put constraints on the freedom of the private finance to innovate. ${ }^{43}$ Private finance thus continues to lead the dance to the extent of marking the current era as one of financial authoritarianism.

In the so-called hard sciences, any theory that would imply results as disastrous as those produced by the laissez-faire approach would have been immediately disqualified. Despite the many attempts by the orthodox theory, fortunately economics remains a soft science. But the disadvantage is that it is more easily bent to serve ideological and vested interests.

\footnotetext{
43 "The goal will be to strengthen the resilience of the system without hindering the process of market discipline and innovation that are essential to the financial sector's contribution to economic growth" (Draghi 2008, 7). "Regulation must not prevent innovation, which is necessary if we are to improve product choices for consumers and an expanded access to credit" (Draghi 2009, 8).
} 


\section{REFERENCES}

BCBS (Basel Committee on Banking Supervision). 2004. "Bank Failures in Mature Economies." Committee on Banking Supervision Working Paper No. 13. Basel: Basel Committee on Banking Supervision.

Bordo, M., O. Humpage, and A. Schwartz. 2011. "U.S. intervention during the Bretton Woods era: 1962-1973." Federal Reserve Bank of Cleveland Working Paper 11-08. Cleveland: Federal Reserve Bank of Cleveland.

Borio, C. 2007. "Change and constancy in the financial system: implications for financial distress and policy." BIS Working Paper No. 237. Basel: Bank for International Settlements.

Bradford, F. 1935. “The Banking Act of 1935.” The American Economic Review 25(4): 661-72.

Buchanan, J., and G. Tullock. 1962. The Calculus of Consent. Ann Arbor, MI: University of Michigan Press.

Burn, G. 1999. "The State, the City and the Euromarkets." Review of International Political Economy 6(2): 225-61.

de Cecco, M. 1979. "The origin of the post-war payments system." Cambridge Economic Journal 3: 49-61.

Draghi, M. 2008. "How to Restore Financial Stability.” Bundesbank Lecture Series. Frankfurt am Main: Deutsche Bundesbank.

- 2009. "Financial Stability in the global environment? Learning the lessons from the market crisis." Keynote Speech at International Organization of Securities Commission's (IOSCO) annual conference, Tel-Aviv, Israel, June 10.

Emmett, R. 2013. Documents Related to J.M. Keynes, Institutionalism at Chicago \& Frank H. Knight. Bingley, UK: Emerald.

Fisher, I. 1932. Booms and Depressions. Some First Principles. New York: Adelphi.

—. 1933. "The debt-deflation theory of great depressions." Econometrica 1(4): 337-57.

Gibson, H. D. 1989. The Eurocurrency markets, domestic financial policy and international instability. London: Macmillan.

Hawtrey, R. 1913. Good and Bad Trade. London: Constable \& Company Limited. 1919. Currency and Credit. London: Longmans. 1932. The Art of Central Banking. London: Longmans. 
1937. Capital and Employment. London: Longmans.

Helleiner, E. 1994. States and the reemergence of global finance. From Bretton Woods to the 1990s. Ithaca, NY: Cornell University Press.

Horsefield, J. K. 1969. The International Monetary Fund, 1945-1965, vol. III: Documents. Washington, DC: International Monetary Fund.

Kaldor, N. 1960. Essays in Stability and Growth. London: Duckworth.

Kalinowski, T. 2011. "Regulating international finance and the evolving imbalance of capitalism since the 1970s." Max Planck Institute for the Study of Societies Working Paper 11/10. Munich: Max Planck Institute for the Study of Societies.

Keynes, J. M. 1930. The Treatise on Money. London: Macmillan. 1933. "National self-sufficiency." The New Statement and Nation, July 8 and 15. The full original version of the Dublin Lecture is reprinted in M. C. Nolan. 2013. Keynes in Dublin. County Cork, Ireland: Maurice Sweeney Editorial and Publishing Services.

— 1936. The General Theory of Employment, Interest and Money. London: Macmillan.

Kregel, J. 1977. "On the existence of expectations in English neoclassical economics." Journal of Economic Literature 15(2): 495-500.

_. 1993. "Keynesian stabilization policy and post war economic performance." in A. Szirmai, B. Van Ark, and D. Pilat (eds.), Explaining Economic Growth: Essays in Honour of Angus Maddison. Amsterdam: North Holland.

- 1996. Origini e sviluppo dei mercati finanziari. Arezzo, Italy: Banca Popolare dell'Etruria e del Lazio, Studi e Ricerche.

1999. "Capital and income in the theory of investment and output: Irving Fisher and John Maynard Keynes." In H. Loef and H. Monissen (eds.), The Economics of Irving Fisher. Cheltenham, UK: Edward Elgar.

_ 2010a. "Can a return to Glass-Steagall provide financial stability in the US financial system?" PSL Quarterly Review 63(252): 39-75.

— 2010b. "Keynes's Influence on Modern Economics: Some Overlooked Contributions of Keynes's Theory of Finance and Economic Policy." In B. Bateman, T. Hirai, and M. C. Marcuzzo (eds.), The Return to Keynes. Cambridge, MA: Harvard University Press.

Laeven, L., and F. Valencia. 2018. Systemic Banking Crises Revisited. International Monetary Fund Working Paper No. WP/18/2016. Washington, DC: International Monetary Fund. 
Lo Duca, M., A. Koban, M. Baste, E. Bengtsson, B. Kalus, P. Kusmierczyk, J. H. Lang, C. Detken, and T. A. Peltonen. 2017. "A new database for financial crises in European countries.” European Systemic Risk Board Occasional Paper No. 194. Frankfurt am Main: European Systemic Risk Board.Marshall, A. 1923. Money, Credit and Commerce. London: Macmillan.

Marshall, A. 1923. Money, Credit and Commerce. London: Macmillan.

Marshall, A., and M. Paley. 1879. The Economics of Industry. London: Macmillan.

Minsky, H. P. 1986. Stabilizing an Unstable Economy. New Haven, CT: Yale University Press. 1991. "The Transition to a Market Economy: Financial Options." Levy Institute Working Paper No. 66. Annandale-on-Hudson, NY: Levy Economics Institute of Bard College.

- 1992. "The Capital Development of the Economy and the Structure of Financial Institutions.” Levy Institute Working Paper No. 72. Annandale-on-Hudson, NY: Levy Economics Institute of Bard College.

Moggridge, D. (ed.) 1980a. The Collected Writings of J.M. Keynes, Activities 1940-1944: Shaping the Post-War World, The Clearing Union, Vol. XXV. Cambridge, UK: Cambridge University Press.

- (ed.) 1980b. The Collected Writings of J.M. Keynes, Activities 1940-1946: Shaping the Post-War World, Employment and Commodities, Vol. XXVII. Cambridge, UK: Cambridge University Press.

Montanaro, E., and M. Tonveronachi. 2011. "A critical assessment of the European approach to financial reforms." PSL Quarterly Review 64(258): 193-226.

Persaud, A. 2002. "Liquidity Black Holes.” UN WIDER Discussion Paper No. 2002/31. Helsinki: WIDER, United Nations University.

Pigou, A. C. 1925. Memorials of Alfred Marshall. London: Macmillan.

Rauchway, E. 2015. The Money Makers. How Roosevelt and Keynes Ended the Depression, Defeated Fascism, and Secured a Prosperous Peace. New York: Basic Books.

Reinhart, C., and K. Rogoff. 2009. This Time Is Different. Princeton, NJ: Princeton University Press.

Robertson, D. H. 1915. A Study of Industrial Fluctuations. London: P. S. King \& Son. 1926. Banking Policy and the Price Level. London: P. S. King \& Son. 
Roncaglia, A. 2005. The Wealth of Ideas. A History of Economic Thought. Cambridge, UK: Cambridge University Press.

- 2019. The Age of Fragmentation. A History of Contemporary Economic Thought. Cambridge, UK: Cambridge University Press.

Roncaglia, A., and M. Tonveronachi. 1985. "Pre-Keynesian roots of the neoclassical synthesis." Cahiers d'Economie Politique 10-11: 51-65.

Schenk, C. 1998. "The origin of the Eurodollar market in London: 1955-1963." Explorations in Economic History 35: 221-38.

Schinasi, G. 2007. "Understanding financial stability: Towards a practical framework." Paper presented at the IMF's Seminar on Current Developments in Monetary and Financial Law, Washington, DC, October 23-27. Available at: https://www.imf.org/external/np/seminars/eng/2006/mfl/gjs.pdf

Terrell, H. S., and R. H. Mills. 1985. "International Banking Facilities and the Eurodollar Market.” In P. Savona and G. Sutija (eds.), Eurodollars and International Banking. London: Palgrave Macmillan.

Tonveronachi, M. 1983. J.M. Keynes. Dall'instabilità ciclica all'equilibrio di sottoccupazione. Rome: La Nuova Italia Scientifica. Available at: https://www.aitomo.it/tonveronachi/pubblicazioni/1983_Tonveronachi_JM\%20Keynes.p df.

— . 2018. "Ending laissez-faire finance.” In M. Corsi, J. Kregel, and C. D’Ippoliti (eds.), Classical Economics Today. Essays in Honor of Alessandro Roncaglia. London: Anthem Press.

UNCTAD (United Nations Conference on Trade and Development). 2009. The Global Economic Crisis: Systemic Failures and Multilateral Remedies. Geneva: United Nations Conference on Trade and Development.

- 2015. Trade and Development Report. Geneva: United Nations Conference on Trade and Development.

- 2019. Trade and Development Report. Geneva: United Nations Conference on Trade and Development.

United States Congress. 1933. "Banking Act.” Available at http://frase.stlouisfed.org.

White, H. D. 1943. "Preliminary draft outline of a proposal for an International Stabilization Fund." In J. K. Horsefield (ed.), The International Monetary Fund, 1945-1965, vol. III: Documents. Washington, DC: International Monetary Fund. 
Wray, L. R. 2011. "Minsky's money manager capitalism and the global financial crisis." Levy Economics Institute Working Paper No. 661. Annandale-on-Hudson, NY: Levy Economics Institute of Bard College. 